\title{
ANALYSIS OF THE INFLUENCE OF BUDGET PLANNING ON MANAGERIAL ACCOUNTABILITY THROUGH BUDGET EVALUATION: A CASE STUDY AT KOPERTIS REGION XII MALUKU AND NORTH MALUKU OF AMBON CITY
}

\author{
Pattiruhu Jose R., Lecturer \\ Study Program of Management, Postgraduate Program, University of Pattimura, Indonesia \\ E-mail: patiruhujoseph01@gmail.com
}

\begin{abstract}
This study aims to look at the effect of budget planning on budget evaluation, budget planning, and budget evaluation on managerial accountability, and budget planning on managerial accountability through budget evaluation. Respondents in this study were Civil Servants who served as Officials and Staff at Kopertis Region XII in Ambon City. The numbers of samples in this study were 30 respondents. The data processing method used is multiple linear regression analysis and continued using path analysis. The results of this study indicate that there is an influence of planning on budget evaluation, budget evaluation on managerial accountability, and budget planning can influence managerial accountability through budget evaluation.
\end{abstract}

\section{KEY WORDS}

Managerial accountability, budget evaluation, budget planning.

Budgeting of a nation is influenced by the budget system used. Indonesia uses a performance-based budgeting system namely a budgeting system that emphasizes the utilization of available funds to achieve optimal results from the implementation of programs and development activities (Yuwono, et al 2008).

Public sector budget is a periodic financial and activity plan (usually in an annual period) that contains programs and activities and the amount of funds obtained (revenue/income) and needed (expense/expenditure) in order to achieve organizational goals (Haryanto, et al (2007) in (Asikin, 2012) (2012). The budget is structured systematically, covering all institutional activities, which are expressed in monetary units and are valid for the future (Mardiasmo, 2002). The budget is made to plan and specify all activity funds in public sector organizations (Höglund et al., 2018; Bryson, 2018; Miller, 2018; Ahrens \& Ferry, 2018)

The important role of the budget in planning is achieved by stating in the value of money the amount of input needed to carry out planned activities in the budget period. One important factor in the performance-based budgeting system is planning. Planning activities will become the foundation for the implementation of the next activities, namely the implementation of the budget. The success or failure of this implementation will greatly depend on the extent to which the quality of planning can be used as a strong and quality foundation for the implementation phase (Jeston, 2004; Livet et al., 2018; Sila, 2018; Eboreime et al., 2018; Eboreime, et al., 2019).

To prevent the dysfunctional impact of the budget, (Supomo, 1998; Monoarfa \& Dama, 2018; Rivito \& Mulyani, 2018; Yanti, 2018; Majid \& Asse, 2018), need to involve management at a lower level in the drafting process. This is intended, so that subordinates feel their aspirations are valued so that they feel responsible for the budgeting process and ultimately can improve performance, in accordance with those targeted in the budget. A good reporting system is needed to be able to monitor and control management performance in implementing a predetermined budget. The government is obliged to provide financial information and other information that will be used for economic, social and political decision making by interested parties (Zakiyudin and Suyanto, 2015).

Munawar (2006) explains that evaluation is an assessment conducted on the budget that has been prepared and knows how much deviation that has occurred can be traced to 
the responsible budget implementers Munawar (2006) explains that evaluation is an assessment conducted on the budget that has been prepared and knows how much deviation that has occurred can be traced to the responsible budget implementers. Munawar (2006) found that budget evaluation affected the behavior of Ambon regional government officials. This shows that in preparing the budget they always evaluate the activities that have been programmed, but at the time of implementation they do not evaluate the activities that have been carried out so that their performance becomes low.

Good public services are reflected in managerial performance measurement. Simanjutak (2005) defines performance as the level of achievement of results or the implementation of certain tasks. Based on the definition according to (Bangun, 2009) managerial performance is the result of effective managerial activity processes starting from the process of planning and budgeting, administration, reporting, accountability and staffing. To conduct performance measurements, the government conducts accounting information primarily to determine performance indicators. Financial performance indicators are reflected in the budget.

Kopertis Region XII is a Private Higher Education Coordination whose working area covers Maluku and North Maluku. Kopertis Region XII oversees 44 private universities spread in Maluku and North Maluku with details 27 private universities in Maluku and 17 in North Maluku.

The current phenomenon, based on LAKIP 2017, can be said that managerial performance in Kopertis Region XII is still not satisfactory. Where the funds' management has not been managed well enough, there are still several reports of activities that are not in accordance with the planning when carrying out activities. This is because the planning and budgeting process is not optimal.

Based on the description above, the formulation of the problem in this study is how the influence of budget planning on budget evaluation, the influence of budget planning and budget evaluation on managerial accountability, and see the effect of budget planning on managerial accountability through budget evaluation? So the purpose of this study is to find out and analyze the effect of budget planning on budget evaluation, influence of budget planning and budget evaluation on managerial accountability, and see the effect of budget planning on managerial accountability through budget evaluation in Kopertis Region XII.

\section{METHODS OF RESEARCH}

This research is a research with survey method using primary data conducted on officials and staff at Kopertis Region XII in Ambon City who involved in budgeting. In this study, the data used to collect this primary data is through a list of statements called questionnaires which directly distributed, and also secondary data in the form of financial reports.

The analysis technique that will be used is regression analysis and will be continued using path analysis, which is used to test the effect of independent variables on the dependent variable. The first step that needs to be done in the data analysis technique, which in this step is testing the validity and reliability of the list of questions asked. After data analysis, the next step is regression analysis.

Validity test is used to measure valid or invalid of a questionnaire (Ghozali, 2009) In order the data obtained can be relevant or in accordance with the purpose of the validity test used is to calculate the correlation between the scores of each item with the score of each construct. This test uses the Pearson Correlation method where researchers want to prove the existence of a relationship between two variables. If the correlation score of each question with each construct will be said to be valid if it is significant at level 0.05 (Ghozali, 2009).

Reliability test is used to determine the minimum level of confidence that can be given to the sincerity of the answers received (Ghozali, 2009). This reliability test uses the Cronbach's alpha ( $\alpha$ ) technique. The criteria for a research instrument are said to be reliable using this technique, if the coefficient of reliability (ri)> 0,7 (Ghozali, 2009). 
Path analysis is the relationship between independent variables, intermediate variables, and dependent variables which are usually presented in the form of diagrams. In the diagram there is an arrow that shows the direction of influence among exogenous, intermediary, and dependent variables. Sometimes the magnitude of influence is described in the thickness of the arrow. Path analysis only relates to multiple regressions with measurable variables.

Path analysis is a statistical technique for testing causal relationships between two or more variables, based on linear equations. This technique was developed since 1939 by Sewall Wright. This causal relationship there is a direct $X \rightarrow Y 2$ and there are also indirect ones but through intermediate variable $Y$ namely $X Y 1 \rightarrow Y 2$. The path described by this arrow is a hypothesis that will be tested based on field data.

Testing the hypothesis will be used path analysis:

$$
\begin{aligned}
& Y 1=\rho Y 1 X 1+\varepsilon \\
& Y 2=\rho Y 2 Y 1+\rho Y 2 X 1+\varepsilon
\end{aligned}
$$

Where: Y2 - Managerial Accountability; Y1 - Budget Evaluation; X1 - Budget Planning; $\rho$ - Probability; $\varepsilon$ - error term.

\section{RESULTS OF STUDY}

In Table 1. variable of budget planning (X1) according to respondents is clear. This can be seen from the average value of 35,9. Which shows that on average the respondents answered with answers 'agree' from each question about budget planning at Kopertis Region XII in 2018. With an average of 35,46 for the variable of managerial accountability shows that according to respondents quite accurate. And for the budget evaluation variable with an average of 13.93 this indicates that the budget evaluation activities carried out respondents were quite good.

Table 1 - Descriptive Statistics of Research Variables

\begin{tabular}{c|c|c|c|c|c}
\hline $\mathrm{n} / \mathrm{n}$ & $\mathrm{N}$ & Minimum & Maximum & Mean & Std. Deviation \\
\hline Planning & 30 & 29.00 & 40.00 & 35.9000 & 3.17696 \\
Evaluation & 30 & 8.00 & 15.00 & 13.9333 & 1.76036 \\
Performance & 30 & 25.00 & 45.00 & 35.4667 & 4.94615 \\
Valid N (listwise) & 30 & & & & \\
\hline
\end{tabular}

Source: Primary data processed by SPSS v23, 2018.

Table 2 - Validity Test Results

\begin{tabular}{c|c|c|c}
\hline Indicator & Correlation Value $(r)$ & Value of Sig & Description \\
\hline X1.1 & 0.557 & 0.3061 & Valid \\
X1.2 & 0.641 & 0.3061 & Valid \\
X1.3 & 0.341 & 0.3061 & Valid \\
X1.4 & 0.666 & 0.3061 & Valid \\
X1.5 & 0.734 & 0.3061 & Valid \\
X1.6 & 0.627 & 0.3061 & Valid \\
X1.7 & 0.816 & 0.3061 & Valid \\
X1.8 & 0.767 & 0.3061 & Valid \\
Y1.1 & 0.849 & 0.3061 & Valid \\
Y1.2 & 0.881 & 0.3061 & Valid \\
Y1.3 & 0.754 & 0.3061 & Valid \\
Y2.1 & 0.583 & 0.3061 & Valid \\
Y2.2 & 0.521 & 0.3061 & Valid \\
Y2.3 & 0.602 & 0.3061 & Valid \\
Y2.4 & 0.620 & 0.3061 & Valid \\
Y2.5 & 0.614 & 0.3061 & Valid \\
Y2.6 & 0.748 & 0.3061 & Valid \\
Y2.7 & 0.381 & 0.3061 & Valid \\
Y2.8 & 0.468 & 0.3061 & Valid \\
Y2.9 & 0.672 & 0.3061 & Valid \\
\hline
\end{tabular}

Source: Primary data processed by SPSS v23, 2018. 
Validity test in this study uses Construct validity testing which is done by correlation techniques between scores of questions in an observed variable with its total score, by using the product moment correlation formula using a significance level of $5 \%$ from its critical value and correlation value (r) (Sugiono, 2012: 133).

From the Table 2, indicates that the value of the Product Moment ( $r$ ) coefficient is greater than 0.3 and the significant value is 0.00 . This means that all indicators / items are declared valid and further testing can be carried out.

Reliability testing in this study uses the cronbach's alpha coefficient test approach on each variable indicator. Reliability testing is conducted by calculating the cronbach's alpha coefficient in each instrument in one variable. One instrument is said to be reliable if it has more than 0,6 cronbach alpha (Nunally, 1978). Reliability test is an instrument in measuring data (Ferdinandus, 207: 268) states that it is reliable or trusted if the instrument consistently produces the same results every time a measurement is made.

Table 3 - Reliability Test Results

\begin{tabular}{c|c|c}
\hline Variable & Cronbach's Alpha Value & Description \\
\hline X1 & 0.786 & Reliable \\
Y1 & 0.765 & Reliable \\
Y2 & 0.748 & Reliable \\
\hline
\end{tabular}

Source: Primary data processed by SPSSv23, 2018.

Data table 3 shows that the cronbach's alpha value is greater than 0.6 namely equal to 0,786 for the budget planning variable $(\mathrm{X} 1)$, for budget evaluation $(\mathrm{Y} 1)$ equal to 0,765 and for managerial accountability (Y2) amounted to 0,748 . This proves that research instruments is reliable. Cronbach's alpha value of all indicators greater than 0.6 means that the criteria are reliable for all indicators for each reliable variable and reliable for further testing (Ghozali, 2009).

The regression model used to see the effect of budget planning on budget evaluation can be formulated as follows:

$$
Y 1=X 1+\varepsilon(3)
$$

Whereas to test the relationship between budget planning (X1), towards managerial accountability (Y2) with budget evaluation $(\mathrm{Y} 1)$ as moderation can be done with a residual test. The regression equation is as follows:

$$
\mathrm{Y} 2=\mathrm{X} 1+\mathrm{Y} 1+\mathrm{X} 1^{*} \mathrm{Y} 1+\varepsilon(4)
$$

To test the first hypothesis of the regression equation above can use a regression test using the t-test. Based on the results of testing using the t-test for the first hypothesis namely budget planning has an effect on the budget evaluation, SPSS output results show a tcalculate value of 2,221 (Table 4) greater than t-table 2,05 with a significance value of 0,03 which means smaller than the alpha significance level of 0,05 , this means budget planning has a positive effect on budget evaluation.

Table 4 - Regression Analysis Results of the Model 1

\begin{tabular}{c|cccc}
\hline Variable & Standarized Coefficient (B) & t calculate & Sig. & Description \\
\hline Constant & & & & Positive and significant \\
Budget Planning (X1) & 0.413 & 2.221 & 0.030 & 0.542 \\
R & & 0.294 & & \\
R-square & & 0.242 & & \\
Adjusted R square & & 5.628 & & \\
F Calculate & & 0.009 & \\
Sig. F & & &
\end{tabular}


Testing the second hypothesis namely budget planning has influence on managerial accountability, SPSS output results show t-calculate value of 0.437 (Table 1.5) smaller than t-table 205 with a significance value of 0,66 , which means greater than the alpha significance level of 0.05 , this means budget planning has no effect on managerial accountability.

The third hypothesis testing namely budget evaluation on managerial accountability, SPSS output results show t-calculate value of 4.454 greater than t-table 2,05 with a significance value of 0.00 , which means greater than the alpha significance level of 0.05 , this means that budget evaluation has an effect on managerial accountability.

Table 5 - Regression Analysis Results of the Model 2

\begin{tabular}{c|cccc}
\hline Variable & Standarized Coefficient $(\mathrm{B})$ & t calculate & Sig. & Description \\
\hline Constant & & & & \\
Budget Planning (X1) & -0.0730 & -0.437 & 0.666 & Not positive and not significant \\
\hline R & & 0.730 & \\
R-square & 0.533 & \\
Adjusted R square & 0.479 & \\
F calculate & 9.896 & \\
Sig. F & 0.000 & \\
\hline
\end{tabular}

From the linear analysis equation model 1 and model 2, then path analysis can be determined which can be used to explain the pattern of relationships between variables in order to determine the direct and indirect effects of a set of independent (exogenous) variables on the dependent variable (endogenous).

Table 6 - Indirect Path Analysis

\begin{tabular}{|c|c|c|c|c|}
\hline No & Path & Direct (not through Y) & Indirect (Through Y1) & Total \\
\hline 1 & $\mathrm{X} 1 \rightarrow \mathrm{Y} 1 \rightarrow \mathrm{Y} 2$ & -0.730 & $0.413 \times 0.710=0.293$ & 0.219 \\
\hline
\end{tabular}

Source: (Primary data 2018, processed).

\section{DISCUSSION OF RESULTS}

This study shows that the first test aims to test whether budget planning has an effect on budget evaluation. Based on the results of statistical tests, it shows that the first hypothesis, namely budget planning, is proven to have an influence on budget evaluation. This can be caused by planning can be used as a control. This is in accordance with the statement of Maryanti (2002); Mischie (2018); Ibrahim (2019); Zamfir \& Florea (2019); Ward et al. (2019), Ford et al. (2019) which states that in preparing the budget it is necessary to evaluate the programmed activities. The budget is one of the final determining factors for a program to receive donor funding. If the budget is too high, donor agency or donors will request a re-evaluation to reduce the amount of funding. The budget planning that has been made must be evaluated and approved by stakeholders so that it can become a guideline for the implementation of the program.

The second hypothesis testing aims to see whether there is an effect of budget planning on managerial accountability. Based on the results of statistical testing shows that budget planning does not have an effect on managerial accountability. These results are not in line with Frost \& Seamer (2002); Basheka (2008); Zakaria et al. (2011); (Asmarani, 2013); Pollanen et al. (2017); revealed that, the relationship between the budget planning with Government Agencies Performance Accountability has a significantly positive correlation. Rosmawati (2011) the results of the study suggest that budget planning is partially and simultaneously having a positive effect on managerial performance.

The third hypothesis testing aims to see whether there is an effect of budget evaluation on managerial accountability. Based on the results of statistical testing shows that the fifth hypothesis, namely budget evaluation is proven to have an influence on managerial accountability. The results of this study are in accordance with previous researchers Salbiah and Risky (2012) who stated that budget evaluation has a significant effect on the 
performance of the SKPD organization of the Government of North Sumatra. The importance of budget evaluation aspects is applied in order to conduct prospectively related to the results of evaluation and follow-up of the use of the budget managed by Kopertis Region XII. This means that budget management activities carried out by Kopertis Region XII to be managed properly need a real program carried out by Kopertis Region XII by using appropriate and accurate evaluation measurement indicators in assessing a budgeting activity that affects the performance of officials. With the evaluation of the budget, it will be known the organization's performance in that period, and is expected to improve organizational performance in the next period (Salbiah and Risky, 2012).

The fourth hypothesis testing aims to see whether there is an effect of budget planning on managerial accountability through budget evaluation. Budget planning variable (X1) has a Beta value $(B)$ at the standardized coefficient on managerial accountability (Y2) through budget evaluation (Y1) greater than Beta $(\mathrm{B})$ at the standardized coefficient on managerial accountability (Y2) namely equal to $0.293>-0.074$, based on the results of the budget planning statistical test provides a significant and positive influence on managerial accountability through budget evaluation at Kopertis Region XII Ambon. The results showed that budget planning influences managerial accountability through budget evaluation in a positive and significant part on managerial accountability with the value of $t$ arithmetic/calculate $>t$ table namely 3,783 $>2,05$. The results of this study are in accordance with previous researchers Asmarani (2013) which concluded that budget planning had an influence on the performance of the SKPD Head. Planning is a process of choosing various alternative uses of resources to achieve certain goals in the future. In other words, planning in this case budget planning is a tool or means to achieve managerial accountability, where performance is a description of the level of achievement of an activity or program in realizing goals, objectives and vision and mission of the organization.

From Figure 1, it can be explained that budget planning directly does not have an effect on managerial accountability, but it gives an effect if through budget evaluation that is equal to 0.293 . And for the total effect of budget planning on managerial accountability through budget evaluation equal to 0.293 which is obtained from the sum of the magnitude of the influence of planning on evaluation with the magnitude of the effect of evaluation on managerial accountability.

\section{CONCLUSION}

From the results of this study it can be concluded that budget planning is proven to have an influence on budget evaluation, and budget evaluation is proven to have an influence on managerial accountability. Budget evaluation is also able to moderating budget planning for managerial accountability.

There needs to be further research related to this problem but other variables need to be added, and also need a wider sample population. And it is expected that with this research can be able to make managerial performance in the Office area of Kopertis Region XII more optimal.

\section{REFERENCES}

1. Ahrens, T., \& Ferry, L. (2018). Institutional entrepreneurship, practice memory, and cultural memory: Choice and creativity in the pursuit of endogenous change of local authority budgeting. Management Accounting Research, 38, 12-21.

2. Asikin, Decky Firmansyah. (2012). Faktor-Faktor Yang Memengaruhi Penyusunan Anggaran Berbasis Kinerja (Studi Empiris Pada Pemerintah Kota Makassar Provinsi Sulawesi Selatan). Skripsi. Fakultas Ekonomi and Bisnis -UniversitasHasanuddin. Makassar.

3. Asmarani, Tias. (2013). Pengaruh Perencanaan Anggaran, Pengelolaan Kas and Pelaporan, Terhadap Kinerja Kepala SKPD (Studi Kasus Pada Pemerintah Kota 
Pematang Siantar). Tesis.Fakultas Ekonomi and Bisnis - Universitas Sumatra Utara. Medan.

4. Bangun, A., (2009). Pengaruh Partisipasi dalam Penyusunan Anggaran, Kejelasan Sasaran Anggaran and Struktur Desentralisasi terhadap Kinerja Manajerial SKPD dengan Pengawasan Internal sebagai Variabel Pemoderasi.Tesis.Pascasarjana Universitas Sumatera Utara Medan.

5. Basheka, B. C. (2008). Procurement planning and accountability of local Government procurement systems in developing countries: Evidence from Uganda. Journal of Public Procurement, 8(3), 379-406.

6. Bryson, J. M. (2018). Strategic planning for public and nonprofit organizations: A guide to strengthening and sustaining organizational achievement. John Wiley \& Sons.

7. Eboreime, E. A., Eyles, J., Nxumalo, N., Eboreime, O. L., \& Ramaswamy, R. (2019). Implementation process and quality of a primary health care system improvement initiative in a decentralized context: a retrospective appraisal using the quality implementation framework. The International journal of health planning and management, 34(1), e369-e386.

8. Eboreime, E. A., Nxumalo, N., Ramaswamy, R., \& Eyles, J. (2018). Strengthening decentralized primary healthcare planning in nigeria using a quality improvement model: how contexts and actors affect implementation. Health policy and planning, 33(6), 715728.

9. Ford, J. D., Sherman, M., Berrang-Ford, L., Llanos, A., Carcamo, C., Harper, S., ... \& Edge, V. (2018). Preparing for the health impacts of climate change in Indigenous communities: The role of community-based adaptation. Global environmental change, 49, 129-139.

10. Frost, G. R., \& Seamer, M. (2002). Adoption of environmental reporting and management practices: an analysis of New South Wales public sector entities. Financial Accountability \& Management, 18(2), 103-127.

11. Ghozali, Imam. (2009). Ekonometrika: Teori Konsep and Aplikasi dengan SPSS 18. Badan Penerbit Universitas Diponegoro.

12. Höglund, L., Holmgren Caicedo, M., Mårtensson, M., \& Svärdsten, F. (2018). Strategic management in the public sector: how tools enable and constrain strategy making. International Public Management Journal, 21(5), 822-849.

13. Ibrahim, M. M. (2019). Designing zero-based budgeting for public organizations. Problems and Perspectives in Management, 17(2).

14. Jeston, J. (2014). Business process management: practical guidelines to successful implementations. Routledge.

15. Livet, M., Blanchard, C., Sorensen, T. D., \& Roth McClurg, M. (2018). An implementation system for medication optimization: Operationalizing comprehensive medication management delivery in primary care. Journal of the American College of Clinical Pharmacy, 1(1), 14-20.

16. Majid, J., \& Asse, A. (2018). TIME Budget Pressure and Turnover Intention with Dysfunctional Accountant Behavior. International Journal of Economics Management and Social Science, 1(1), 9-16.

17. Maryanti. (2002). Pengaruh Karakteristik Tujuan Anggaran Terhadap Perilaku, Sikap and Kinerja Pemerintah Daerah di Propinsi Nusa Tenggara Timur. Tesis Program Pasca Sarjana, Universitas Gajah Mada. Yogyakarta.

18. Miller, G. (2018). Performance based budgeting. Routledge.

19. Mischie, I. (2018). Factors Of Influence And Limitations Of The Planning, Programming, Budgeting And Execution/Evaluation System (Ppbes) In The Romanian Armed Forces. In International Scientific Conference" Strategies XXI" (Vol. 2, pp. 33-38). " Carol I" National Defence University.

20. Monoarfa, R., \& Dama, H. (2018). The Influence of Time Budget Pressure and Dysfunctional Behavior to Audit Quality at Bawasda in Gorontalo Province. Jurnal Akuntansi, 22(3), 420-436. 
21. Munawar (2006) Pengaruh karakteristik Tujuan Anggaran Terhadap Perilaku, Sikap, danKinerja Pemerintah Daerah Kupang.Simposium Nasional Akuntansi IX.

22. Nunnally, J. C. (1978). Psychometric theory (2nd ed.). McGraw-Hill.

23. Pollanen, R., Abdel-Maksoud, A., Elbanna, S., \& Mahama, H. (2017). Relationships between strategic performance measures, strategic decision-making, and organizational performance: empirical evidence from Canadian public organizations. Public Management Review, 19(5), 725-746.

24. Putra, Deki. (2013). Pengaruh Akuntabilitas Publik and Kejelasan Sasaran Anggaran Terhadap Kinerja Manajerial Satuan Kerja Perangkat Daerah (Studi Empiris pada Satuan Kerja Perangkat Daerah Kota Padang). Skripsi. Universitas Negeri Padang.

25. Rivito, A., \& Mulyani, S. (2019). The Effect of Budget Participation on Local Government Performance with Organizational Commitment as Moderating Variable. Journal of Accounting Auditing and Business, 2(2), 90-103.

26. Rosmawati. (2011). Pengaruh Perencanaan and Pengawasan Anggaran terhadap Kinerja Manajerial pada SKPD Kabupaten Aceh Utara dengan Partisipasi Anggaran Sebagai variabel Moderating.Tesis. Fakultas Ekonomi and Bisnis - Universitas Sumatra Utara. Medan.

27. Salbiah and Rizky, Ridha. (2012). Pengaruh Evaluasi Anggaran Terhadap Kinerja Satuan Kerja Perangkatdaerah (SKPD) Pemerintah Provinsi Sumatera Utara. Jurnal Ekonom, Vol 15, No 2, Hal. 42-52.

28. Sila, I. (2018). Linking Quality with Social and Financial Performance: A Contextual, Ethics-Based Approach. Production and Operations Management, 27(6), 1102-1123.

29. Simanjuntak, Binsar H. (2005). "MenyongsongEra Baru Akuntansi.Pemerintah di Indonesia". Jurnal Akuntansi Pemerintah, Vol 1. No 1.

30. Sugiyono. (2013). Metode Penelitian Kuantitatif Kualitatif and R\&D. Alfabeta.

31. Supomo Bambang and Indriantoro Nur. (1998). Pengaruh Struktur and Kultur Organisasional terhadap Keefektifan Anggaran Partisipatif dalam Peningkatan Kinerja Manajerial: Studi Empiris pada Perusahaan Manufaktur di Indonesia, Kelola No. 18/VII: 61-84.

32. Ward, S., Chow, A. F., Humbert, M. L., Bélanger, M., Muhajarine, N., Vatanparast, H., \& Leis, A. (2018). Promoting physical activity, healthy eating and gross motor skills development among preschoolers attending childcare centers: Process evaluation of the Healthy Start-Départ Santé intervention using the RE-AIM framework. Evaluation and program planning, 68, 90-98.

33. Yanti, W. F. (2018, September). The Effect Of Time Budget Pressure, Locus Of Control, Organizational Commitment, And Performance Auditor Of Auditor Dysfunctional Behaviors (An Empirical Study in Public Accountant Firm DKI Jakarta). In Proceedings (Vol. 1, No. 1).

34. Yuwono, Sony, Dwi Cahyo Utomo, H Suheiry Zeindan H Azrafiany A.R. (2008). Memahami APBD and Permasalahnnya: Panduan PengelolaanKeuangan Daerah. Bayumedia Publishing.

35. Zakaria, W. Z. W., Rahman, S. F., \& Elsayed, M. (2011). An analysis of task performance outcomes through e-accounting in Malaysia. Journal of Public Administration and Governance, 1(2), 124-139.

36. Zakiyudin, M. Ali and Suyanto. (2015). Kejelasan Sasaran Anggaran, Pengendalian Akuntansi, Sistem Pelaporan and Akuntabilitas Kinerja Instansi Pemerintah pada Inspektorat Jenderal Kementerian Agama RI. Jurnal Riset akuntansi and Perpajakan. Jurnal Riset and Perpajakan. ISSN 2339-1545. Vol, 2 No. 1, 2015. Universitas Pancasila.

37. Zamfir, M. P., \& Florea, C. F. (2019). The Budget-Reference System in Assessing the Performance of the Public Enterprise. Academic Journal of Economic Studies, 5(2), 144158. 